\title{
THE INFLUENCE OF DISCIPLINE, RESPONSIBILITY, COOPERATION, AND PROBLEM AWARENESS ON EMPLOYABILITY SKILLS
}

\author{
Budi Santosa ${ }^{1,}$, , Pramudita Budiastuti ${ }^{2}$, Purnawan ${ }^{3}$, Muhammad Sayuti ${ }^{4}$ \\ ${ }^{1,4}$ Study Program of Vocational Education, Universitas Ahmad Dahlan, J1. Pramuka No. 42 Sidikan, Yogyakarta 5516, \\ Indonesia \\ ${ }^{2}$ Study Program of Electronics Engineering Vocational Education, Universitas Ahmad Dahlan, Jl. Ring Road Selatan, \\ Tamanan, Banguntapan, Bantul, Yogyakarta 55166, Indonesia \\ ${ }^{3}$ Study Program of Automotive Technology Vocational Education, Universitas Ahmad Dahlan, Jl. Ahmad Yani (Ringroad \\ Selatan) Tamanan Banguntapan Bantul Yogyakarta 55166, Indonesia \\ E-mail: budi.santosa@mpv.uad.ac.id * \\ *Corresponding Author
}

\begin{abstract}
The purpose of this study was to analyze the influence of discipline, cooperation, responsibility, and problem awareness on employability skills individually and collectively. This study also aims to predict other factors that affect employability skills. The research method used correlational quantitative. Regression analysis was used to predict other factors that affect employability skills. The respondents consisted of 323 students from Muhammadiyah Vocational High Schools in Yogyakarta Province. The results showed that; (1) there is a significant effect between discipline and employability skills with an r-value of $0.588,(2)$ there is a significant influence between responsibility and employability skills with an r-value of 0.568 , (3) there is a significant effect between collaboration and employability skills with an r-value of 0.501 , (4) there is a significant effect between awareness of the problem and employability skills, with an r-value of $0.450,(5)$ there is a significant effect together between discipline, responsibility, cooperation, and awareness of the problem with employability skills with an $\mathrm{r}$ value of 0.691 .
\end{abstract}

Keywords: cooperation, discipline, employability skills, problem awareness, responsibility

\section{INTRODUCTION}

Data on unemployed vocational education graduates from 2017 to 2019 shows an increase as presented in Figure 1. The data are quite concerning because the purpose of vocational education is to prepare graduates for work. Several reasons for the high unemployment rate of vocational high school graduates are: the learning process does not match the needs of the industry, the assessment model does not have recognition by the industry, student skills are still low, the relationship between school and industry is inadequate, teacher qualifications are still low, and school management is not effective.

Vocational education prepares graduates for work. Graduates who are ready to work are the goal of vocational education. However, Vocational High School graduates are not entirely absorbed in the world of work. There is a sizable comparison between vocational high school graduates who are working and unemployed. The graduates who are still at the unemployment stage can be identified. The identification results indicate several factors that cause graduates to be at the unemployment stage, namely low school alumni, low skills and work mentality, and low job availability. Before students approach graduation, the schools need to develop students' career maturity. It can be enhanced by providing career guidance. Students with low career maturity need special attention so that graduates who are still at the unemployment stage can prepare themselves to develop abilities [1]. An indicator of low career maturity is shown by students who have not thought further after leaving school. Students do not know the type of work that is suitable for them and do not know information about a career or further study. Students determine careers only by following the career direction of their friends. 


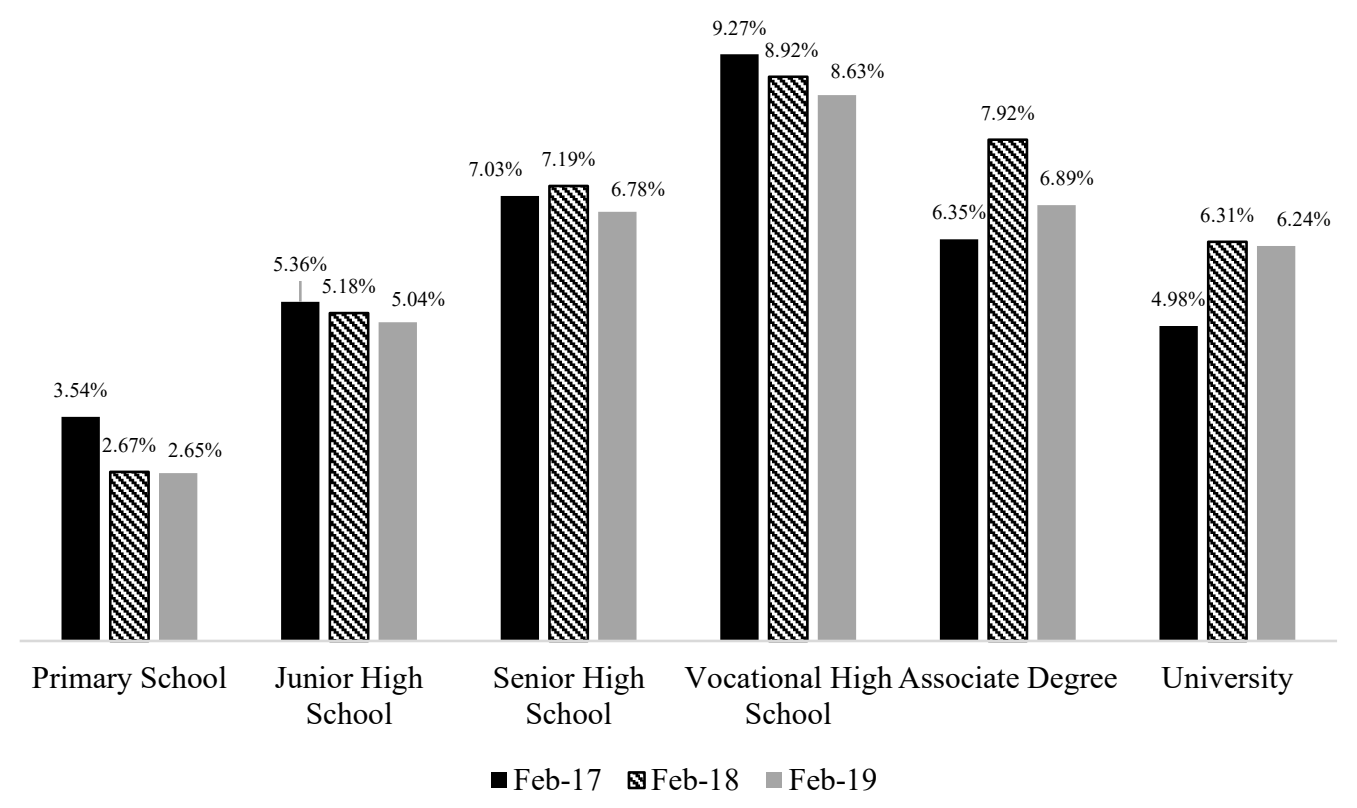

Figure 1. Unemployment Data Based on Education Level in Indonesia from 2017 to 2019 [2]

This behavior can be concluded as behavior that lacks career maturity in terms of career awareness. To increase career awareness, students can apply the theory of Ginzberg's career development using Modeling techniques. Ginsberg, with a Modeling technique, can increase career awareness [3]. Good career awareness is shown by work following the competence of vocational high school graduates. There are still gaps between the job and the competencies they have. Graduates who already have jobs and still have jobs tend to choose not according to their competencies or abilities. Students tend to obtain a job/business with much exertion but meager wages. Students stay away from jobs/businesses with brain work and are well paid. The nature of students who tend to choose jobs/businesses that are not following their competence or ability impacts applying the skills that have been owned and honed for a long time, which is not optimal. Students are weak in understanding their competencies or abilities. The concept of self-understanding can be honed through independence. The application of group guidance with effective problem-solving techniques to increase self-efficacy and assignment scores [4]. The maximum applied assignment group guidance can increase student independence. This increase has a good impact in shaping the character of independence in choosing a career [5].

The maximum character of student independence that is developed will have a good impact on employability skills. The problem of unemployment for vocational high school graduates can be overcome by implementing employability skills development. Development of employability skills can be done by implementing the scientific method [6]. If the unemployment problem is a school obligation (internal), job availability (external) is beyond its control. Schools through industrial work practices provide experience for students to learn the work environment. Industrial work practices are deemed insufficient to motivate students to enter the world of work. Implementing industrial work practices that do not motivate students to enter the world of work needs to be improved. Improvements in the implementation of industrial practices can be viewed by management. Good industrial practice management takes into account the soft skills partially and simultaneously. Industrial practices appropriately managed and paying attention to students' soft skills can improve job readiness [7]. Assessment of the level of work readiness by 
industrial practice experience, the assessment process can use a work-based assessment. The work-based assessment combines the learning process and the assessment process that is carried out when students do industrial work practices using student work patterns in real work [8].

In addition to bringing students closer to the work environment through industrial practice, schools build career centers. Career center as a mediator between school and industry must be active in grouping students who want to get a job or study and facilitate the recruitment process. The career center strengthens students' awareness in choosing a career. A career center developed by the school provides students with awareness to develop employability skills [9]. Government support for vocational secondary school curriculum policies is very important. The government, which tends to change policies, hopes to support integration between vocational high schools and the world of work [10].

Employability skills form the essential attitudes of students as individuals need to be considered. Several basic/innate attitudes can shape students' employability skills. The role of necessary attitude/ innate discipline and responsibility constitutes the attitude of employability skills. Teachers play an essential role in exemplifying discipline and responsibility. Teachers think that students' character values can be developed only through learning and attitudes habituation. The teacher's role model of character values has not been maximal, resulting in the formation of student character that is not optimal because the teacher as an example is not enough to provide examples of application. To achieve success in instilling character values, especially discipline and responsibility, is through religious education teachers' active role as the leading supporter [11]. In addition to activating the role of religious education, the implementation of school discipline will run well if teachers, school officials, and students support disciplinary rules. School rules are rules that must be obeyed by every school member. There are still school residents who do not support the school rules that are implemented in its implementation. The successful application of school discipline can be improved by group guidance with individual counseling techniques when it is required. The application of individualized counseling techniques can improve discipline.

Apart from discipline and responsibility, students' employability skills can be formed through developing a cooperative attitude. By developing a cooperative attitude, students are trained to solve a problem in groups to have strong interaction and tolerance between group members. The development of an attitude of cooperation has a positive impact, namely students have an awareness of the problem. To improve cooperation skills, vocational high school students can apply the cooperative learning model. It emphasizes students' thinking abilities and their skills in expressing understanding using their language [12].

Students' employability skills are formed by a variety of students' basic/innate attitudes. This study aims to analyze the necessary innate characters to build employability skills. It examines the influence of discipline, cooperation, responsibility, and awareness of the problem on employability skills individually and collectively. This study also contributes to predicting other factors that affect employability skills.

\section{METHOD}

This study used quantitative methods to analyze the effect of discipline, cooperation, responsibility, and awareness on employability skills. The respondents are from the Muhammadiyah vocational high schools in the Special Region of Yogyakarta. The sample consisted of 323 students from vocational high schools Muhammadiyah in Yogyakarta City, Bantul Regency, Sleman Regency, and Gunung Kidul Regency. This study was nonexperimental educational research. The research method was descriptive. It was conducted to make systematic, factual, and accurate descriptions of the facts and characteristics of the 
research subject.

The validity used factor analysis, based on the results of the validity test of the instrument it was concluded that all items of the instrument statement were valid. The reliability used Cronbach's Alpha. Based on the results of the instrument reliability test, it was concluded that all items of the instrument statement were reliable. The prerequisite tests consist of linearity, multicollinearity, autocorrelation, heteroscedasticity, and normality testing.

\section{RESULTS AND DISCUSSION}

The results of the linear test between the discipline and employability skills were $0.878>$ 0.05 . The significance value of deviation from linearity can be concluded as a linear relationship between the discipline and employability skills. Sig value. deviation from linearity between cooperation and employability skills of $0.123>$ 0.05 , it can be concluded that there is a linear relationship between cooperation and employability skills. Sig value. deviation from linearity between responsibility and employability skills of $0.075>0.05$, it can be concluded that there is a linear relationship between responsibility and employability skills. Sig value. deviation from linearity between awareness of the problem and employability skills of $0.291>0.05$, it can be concluded that there is a linear relationship between awareness of the problem and employability skills.

Based on the results of the multicollinearity test using the tolerance and VIF methods, it is known that the tolerance value is $>$ 0.10 and the VIF value is $<10.00$. The tolerance value and VIF value can be concluded that the regression model influences discipline, cooperation, responsibility, and the problem awareness of employability skills and does not have multicollinearity symptoms. The results of the multicollinearity test using the tolerance and VIF methods are presented in Table 1.

Based on the results of the $\mathrm{dl}$ value 1.79775 , the du value 1.83559 , the 4 -dl score 2.20225, the 4-du score 2.16441. The autocorrelation test using Durbin Watson is that there is no autocorrelation because the du value is $1.83559<\mathrm{d} 1.932<4-\mathrm{du} 2.16441$. The results of the autocorrelation test using Durbin Watson are presented in Table 2.

Based on the results of the heteroscedasticity test using Glejser, it is known that the Sig. $>0.05$. Sig value. $>0.05$, it can be concluded that there are no heteroscedasticity symptoms in the regression model of the influence of discipline, cooperation, responsibility, and awareness of the problem of employability skills. The results of the heteroscedasticity test using Glejser are presented in Table 3.

Table 1. The Results of the Multicollinearity Test Using the Tolerance and VIF Methods

\begin{tabular}{|c|c|c|c|c|c|c|c|}
\hline \multirow{3}{*}{ Model } & & & \multirow{3}{*}{$\begin{array}{c}\text { Coefficients }{ }^{\mathrm{a}} \\
\text { Standardized } \\
\text { Coefficients } \\
\text { Beta }\end{array}$} & \multirow{3}{*}{$\mathrm{t}$} & \multirow{3}{*}{ Sig. } & \multirow{2}{*}{\multicolumn{2}{|c|}{ Collinearity Statistics }} \\
\hline & \multicolumn{2}{|c|}{$\begin{array}{l}\text { Unstandardized } \\
\text { Coefficients }\end{array}$} & & & & & \\
\hline & $\mathrm{B}$ & Std. Error & & & & Tolerance & VIF \\
\hline$\overline{\text { (Constant) }}$ & 5.397 & 1.406 & & 3.840 & 0.000 & & \\
\hline Discipline & 0.291 & 0.050 & 0.302 & 5.832 & 0.000 & 0.614 & 1.629 \\
\hline Cooperation & 0.244 & 0.048 & 0.264 & 5.086 & 0.000 & 0.612 & 1.634 \\
\hline Responsibility & 0.181 & 0.046 & 0.192 & 3.967 & 0.000 & 0.702 & 1.425 \\
\hline Problem awareness & 0.130 & 0.053 & 0.119 & 2.461 & 0.014 & 0.708 & 1.413 \\
\hline & & Dependent & Variable: Empl & ability & ills & & \\
\hline
\end{tabular}

Table 2. The Results of the Autocorrelation Test Using Durbin Watson

\begin{tabular}{|c|c|c|c|c|c|}
\hline \multirow[b]{2}{*}{ Model } & \multicolumn{5}{|c|}{ Model Summary ${ }^{b}$} \\
\hline & $\mathrm{R}$ & R Square & $\begin{array}{l}\text { Adjusted R } \\
\text { Square }\end{array}$ & $\begin{array}{l}\text { Std. Error of the } \\
\text { Estimate }\end{array}$ & $\begin{array}{l}\text { Durbin- } \\
\text { Watson }\end{array}$ \\
\hline 1 & $0.691^{\mathrm{a}}$ & 0.477 & 0.470 & 2.59154 & 1.932 \\
\hline & $\begin{array}{l}\text { a. Predictors: } \\
\text { b. Dependent }\end{array}$ & $\begin{array}{l}\text { t), Problem } \\
\text { : Employab }\end{array}$ & $\begin{array}{l}\text { areness, Resp } \\
\text { y skills }\end{array}$ & bility, Discipline, C & operation \\
\hline
\end{tabular}


Table 3. The Results of the Heteroscedasticity Test Using Glejser

\begin{tabular}{|c|c|c|c|c|c|}
\hline \multirow[t]{2}{*}{ Model } & \multicolumn{2}{|c|}{$\begin{array}{l}\text { Unstandardized } \\
\text { Coefficients }\end{array}$} & \multirow{2}{*}{$\begin{array}{l}\text { Standardized } \\
\text { Coefficients }\end{array}$} & \multirow[t]{2}{*}{$\mathrm{t}$} & \multirow[t]{2}{*}{ Sig. } \\
\hline & $\overline{\mathrm{B}}$ & Std. Error & & & \\
\hline (Constant) & 3.293 & 0.848 & & 3.885 & 0.000 \\
\hline Discipline & -0.012 & 0.030 & -0.028 & -0.390 & 0.697 \\
\hline Cooperation & -0.041 & 0.029 & -0.101 & -1.413 & 0.159 \\
\hline Responsibility & 0.013 & 0.028 & 0.030 & 0.456 & 0.649 \\
\hline Problem awareness & -0.009 & 0.032 & -0.019 & -0.289 & 0.772 \\
\hline a. Dependent V & able: RES2 & & & & \\
\hline
\end{tabular}

Based on the normality test using the Kolmogorov Smirnov significance value equal to 0.200 . Significance value equal to $0.200>$ 0.05 , it can be concluded that the residual value is normally distributed. The residual values that are normally distributed are a measure that these variables can proceed to regression analysis. The results of the normality test using the Kolmogorov Smirnov are presented in Table 4.

The first hypothesis testing (H1) is the effect of discipline on employability skills. The significance of the effect of discipline on employability skills is $0.000<0.05$. It can be concluded that (H1) is accepted, which indicates an effect of discipline on employability skills.

The second hypothesis testing (H2) is the effect of cooperation on employability skills. The significance of the effect of responsibility on employability skills is $0.000<0.05$. It can be concluded that $(\mathrm{H} 2)$ is accepted, indicating an effect of cooperation on employability skills.

The third hypothesis testing $(\mathrm{H} 3)$ is the effect of responsibility on employability skills.
The significance of the effect of responsibility on employability skills is $0.000<0.05$. It can be concluded that $(\mathrm{H} 3)$ is accepted, which indicates the effect of responsibility on employability skills.

The fourth hypothesis (H4) is the effect of problem awareness on employability skills. The significance for the effect of awareness of the problem on employability skills is $0.014<0.05$. It can be concluded that (H4) is accepted, which indicates an effect of responsibility on employability skills.

The fifth hypothesis (H5) is the effect of discipline, cooperation, responsibility, and problem awareness on employability skills. The significant effect of discipline, cooperation, responsibility, and the problem awareness of employability skills together is $0.000<0.05$. It can be concluded that (H5) is accepted, which indicates discipline, cooperation, responsibility, and problem awareness simultaneously on employability skills. The hypothesis testing is presented in Table 5 and Table 6.

Table 4. The Results of Normality Test Using the Kolmogorov Smirnov

\begin{tabular}{lrr}
\hline & One-Sample Kolmogorov-Smirnov Test \\
\hline $\mathrm{N}$ & & Unstandardized Residual \\
Normal Parameters ${ }^{\mathrm{a}, \mathrm{b}}$ & & 323 \\
& Mean & 0.0000000 \\
Most Extreme Differences & Std. Deviation & 2.57539774 \\
& Absolute & 0.028 \\
& Positive & 0.028 \\
Test Statistic & Negative & -0.021 \\
Asymp. Sig. (2-tailed) & & 0.028 \\
\hline
\end{tabular}

a. Test distribution is Normal

b. Calculated from data

c. Lilliefors Significance Correction

$\mathrm{d}$. This is a lower bound of the true significance 
Table 5. The Hypothesis Testing

\begin{tabular}{|c|c|c|c|c|c|}
\hline \multirow{3}{*}{ Model } & \multicolumn{4}{|c|}{ Coefficients $^{\mathrm{a}}$} & \multirow{3}{*}{ Sig. } \\
\hline & \multicolumn{2}{|c|}{ Unstandardized Coefficients } & \multirow{2}{*}{$\frac{\text { Standardized Coefficients }}{\text { Beta }}$} & \multirow{2}{*}{$\mathrm{t}$} & \\
\hline & $\mathrm{B}$ & Std. Error & & & \\
\hline (Constant) & 5.397 & 1.406 & & 3.840 & 0.000 \\
\hline Discipline & 0.291 & 0.50 & 0.032 & 5.832 & 0.000 \\
\hline Cooperation & 0.244 & 0.48 & 0.264 & 5.086 & 0.000 \\
\hline Responsibility & 0.181 & 0.46 & 0.192 & 3.967 & 0.000 \\
\hline Problem awareness & 0.130 & 0.53 & 0.119 & 2.461 & 0.014 \\
\hline a. Dependent $\mathrm{Va}$ & : Emplo & Eills & & & \\
\hline
\end{tabular}

Table 6. The Hypothesis Testing

\begin{tabular}{ccccccc}
\hline & \multicolumn{5}{c}{ Anova $^{\mathrm{a}}$} \\
\hline \multirow{2}{*}{ Model } & $\begin{array}{c}\text { Sum of } \\
\text { Square }\end{array}$ & df & $\begin{array}{c}\text { Mean } \\
\text { Square }\end{array}$ & F & Sig. \\
\hline & Regression & 1947.672 & 4 & 486.918 & 72.500 & $0.000^{\mathrm{b}}$ \\
& Residual & 2135.721 & 318 & 6.716 & & \\
Total & 4083.393 & 322 & & & \\
\hline
\end{tabular}

a. Dependent Variable: Employability skills

b. Predictors: (Constant), Problem awareness (X4), Responsibility (X3), Discipline (X1), Cooperation (X2)

Discussion of the results of the first hypothesis (H1), second hypothesis (H2), third hypothesis (H3), hypothesis (H4), and hypothesis (H5) are as follows. Discipline has a significant effect on employability skills. This hypothesis can provide information that the higher the student's perception of discipline, the higher the employability skills, and vice versa. Based on the research that has been done, it is known that superior disciplinary indicators are students tend to obey the rules applied by the school, and students tend to complete assignments on time. Farihati et al. [13] reported that that students' discipline will make students accustomed to following, obeying applicable rules and routine habits will build a good personality. Prasasty [14] indicated that discipline needs to be developed on real experiences in students' daily lives. If the discipline of students of Muhammadiyah vocational high school Yogyakarta Province already exists. It can be ascertained that these students have employability skills. The effect of discipline on employability skills in this research is based on students' perception at the Muhammadiyah vocational high school, Yogyakarta Province, not based on grades.

Cooperation has a significant effect on employability skills. This hypothesis can provide information that the higher the perception of cooperation, the higher the employability skills.
The lower the students' perception of cooperation, the lower the employability skills. It is known that the superior indicator of cooperation is that students tend to make decisions together in groups. Students communicate effectively with friends in the group, and students always help friends who need help. Margunani \& Nila [15] revealed that the nature of cooperation shows that students can maintain good relationships with colleagues and instructors. That is an essential provision in entering the world of work. Besides, Alifah et al. [16] found that the ability to establish and maintain good relationships can be realized by not patronizing each other so that no one is superior to one another. When cooperation of vocational high school students Muhammadiyah Yogyakarta province already exists, it indicates students have employability skills. The measurement of the effect of cooperation on employability skills in this research is based on students' perceptions at the Muhammadiyah vocational high school, Yogyakarta Province, not based on grades.

Responsibility has a significant effect on employability skills. This hypothesis can provide information that the higher the perception of responsibility, the higher the employability skills. The lower the students' perception of responsibility, the lower the employability skills. A superior indicator of responsibility is that 
students tend to try to solve difficulties independently. Besides, students tend to complete assignments to completion. Ismayani [17] found that giving freedom and trust to students in the learning process will increase a sense of responsibility. Increased responsibility of being the capital of students to be a creative individual and are ready to face life/world outside of the context of learning. Besides, Hanim et al. [18] reported that aspects of responsibility that become students' capital to face life/world outside the context of learning are willing to take risks, independence, bonding to tasks, and quality work results. If the responsibility of the Yogyakarta Province Muhammadiyah vocational high school students already exists, it means that these students have employability skills. Measuring the effect of responsibility on employability skills in this research is based on student perceptions at the Muhammadiyah vocational high school, Yogyakarta Province, not based on grades.

Awareness of the problem has a significant effect on employability skills. This hypothesis can provide information that the higher the perceptions of awareness of the student problem, the higher the employability skills. The lower the students' perceived awareness of the problem, the lower the employability skills. The indicator of superior problem awareness is that students tend to understand the impact of short-term and long-term actions/behaviors performed. Wahyuni [19] concluded that awareness of problems can be manifested by controlling daily behavior or actions to become aware of one's performance. This awareness is essential for students to be themselves who have a tolerant attitude and help each other. This awareness is essential for students to be themselves who have a tolerant attitude and help each other. Awareness is an effort to build a good relationship between people and adapt to the environment [19]. Also, Aripin [20] associated behaviors with career planning awareness, improved awareness behavioral in the students themselves useful in directing or be one of the considerations of planning a career in the future following their talents, interests, potential, strengths, weaknesses, and domains of other aspects within. If the students have problem awareness, it can be considered that the students have employability skills. Measuring awareness of the problem on employability skills in this research is based on student perception students at the Muhammadiyah Vocational High School, Yogyakarta Province, not based on grades.

Discipline, cooperation, responsibility, and awareness of problems have a significant effect on employability skills. This hypothesis indicates that the higher the perceptions of discipline, cooperation, responsibility, and problem awareness, the higher the employability skills will be. The lower the perceptions of discipline, cooperation, responsibility, and problem awareness by students, the lower the employability skills will be. Krisnamurti [21] and Baser et al. [22] found that many factors or variables can affect job readiness, both within the students themselves and outside. The students themselves determine the level of work readiness that is owned by students. Other factors that exist outside of the student are supportive. Although only as a support, it must still be considered. Factors or variables that affect employability skills in this study are disciplines, cooperation, responsibility, and awareness of problems. These factors or variables are character values that come from within the students themselves. If the discipline, cooperation, responsibility, and problem awareness of the Yogyakarta Province Muhammadiyah vocational high school students already exist. It can be confirmed that these students have employability skills.

\section{CONCLUSION}

The findings of this study revealed that there is an influence between discipline and employability skills with an r-value of 0.588 . There is an influence between responsibility and employability skills with an r-value of 0.568 . There is an influence between cooperation and employability skills with an r-value of 0.501 . 
There is an influence between the awareness of the problem with employability skills with an $\mathrm{r}$ value of 0.450 . There is a mutual influence between discipline, responsibility, cooperation, and awareness of the problem with employability skills with an r-value of 0.691 . Factors or variables that affect job readiness in this research are disciplines, cooperation, responsibility, and awareness of problems. These factors or variables are character values that come from within the students themselves Other factors that exist outside of the student are supportive.

\section{ACKNOWLEDGEMENT}

The authors are grateful to the principals od Vocational High Schools Muhammadiyah 1 Yogyakarta, Muhammadiyah 1 Tempel, Muhammadiyah 1 Playen, Muhammadiyah Imogiri and the Head of Institute for Research and Community Service, Ahmad Dahlan University.

\section{REFERENCES}

[1] I. Z. Ratnaningsih, E. R. Kustanti, A. R. Prasetyo, and N. Fauziah, "Kematangan karir siswa sekolah kejuruan ditinjau dari jenis kelamin dan jurusan," Humanit. Indones. Psychol. J., vol. 13, no. 2, p. 121, Mar. 2016, doi: 10.26555/humanitas.v13i2.6067.

[2] Badan Pusat Statistik, "Keadaan ketenagakerjaan Indonesia Agustus 2019," Jakarta, 2019.

[3] A. Verianto, K. Suranata, I. Ketut Dharsana, and J. B. Konseling, "Penerapan model perkembangan karir Ginzberg dengan menggunakan teknik modeling untuk meningkatkan kesadaran karir pada siswa kelas X TKR3 SMK Negeri 3 Singaraja" J. Ilm. Bimbing. Konseling, vol. 2, no. 1, Aug.2014, doi:10.23887/JIBK.V2I1.3933.

[4] A. Muzamil, M. E. Wibowo, and E. Purwanto, "The Effectivenes of Group
Guidance with Problem Solving Technique to Improve Self-Efficacy and Task Value," J. Bimbing. Konseling, vol. 8, no. 1, pp. 6-10, 2019, Accessed: Apr. 18, 2021. [Online]. Available: https://journal.unnes.ac.id/sju/index.php/ jubk/article/view/26615.

[5] G. Hortensi, "Penerapan bimbingan kelompok dengan teknik konseling individu dapat meningkatkan disiplin belajar siswa SMK Negeri 5 Mataram," Indones. J. Educ. Dev., vol. 1, no. 2, pp. 159-169, 2020.

[6] S. Sunardi, P. Purnomo, and E. Sutadji, "Pengembangan employability skills siswa SMK ditinjau dari implementasi pendekatan saintifik [Development of Employability Skills for Junior High School Students in terms of the implementation of the scientific approach]," J. Pendidik. Teor. Penelitian, Pengemb., vol. 1, no. 7, pp. 391-1398, 2016, doi: 10.17977/jp.v1i7.6582.

[7] I. Yulianti and M. Khafid, "Pengaruh pengalaman praktik kerja industri, motivasi memasuki dunia kerja, dan kemampuan soft skills terhadap tingkat kesiapan kerja siswa kelas XII kompetensi keahlian akuntansi di SMK Negeri 2 semarang tahun ajaran 2014/2015," Econ. Educ. Anal. J., vol. 4, no. 2, pp. 389-403, 2015, [Online]. Available:

https://journal.unnes.ac.id/sju/index.php/ eeaj/article/view/6771.

[8] B. Santosa and S. Dwi, "Work-based assessment at vocational high school in Indonesia," Int. J. Res. Stud. Educ., vol. 8, no. 1, pp. 89-97, Jun. 2018, doi: 10.5861/ijrse.2018.3011.

[9] L. Indana and Soenarto, "Vocational Career Center as the Bridge between Industry and Vocational High School Graduates," J. Pendidik. Teknol. dan Kejuru., vol. 25, no. 2, pp. 219-228, 2019.

[10] F. Kazilan, R. Hamzah, and A. Bakar, 
"Employability skills among the students of technical and vocational training centers in Malaysia," Eur. J. Soc. Sci., vol. 9, no. 1, pp. 147-160, 2009.

[11] A. Sugiana and S. Sofyan, "Penanaman nilai karakter disiplin dan tanggung jawab di SMK Ethika Palembang [Inculcating Discipline and Responsibility Character Values at SMK Ethika Palembang]," J. PAI Raden Fatah, vol. 1, no. 1, pp. 105-116, 2019.

[12] E. A. Setiyowati and J. A. Pramukantoro, "Model pembelajaran kooperatif murder untuk meningkatkan hasil belajar siswa pada kompetensi inti elektronika di SMK Negeri Nganjuk [MURDER Cooperative Learning Model to Improve Student Learning Outcomes in the Core Competencies of Electronic Engineering]," J. Pendidik. Tek. Elektro, vol. 3, no. 1, pp. 155-162, Jan. 2014, Accessed: Apr. 18, 2021. [Online]. Available:

https://jurnalmahasiswa.unesa.ac.id/inde x.php/jurnal-pendidikan-teknikelektro/article/view/6775.

[13] I. Farihati, K. Bashori, and F. Tentama, "Kedisiplinan, kemandirian dan kesiapan kerja (employability): Literature review [Discipline, independence and work readiness (employability): Literature review]," in Prosiding Seminar Nasional Magister Psikologi Universitas Ahmad Dahlan, Nov. 2019, vol. 0, no. 0, pp. 384-390, Accessed: Apr. 18, 2021. [Online].Available:http://seminar.uad.ac. id/index.php/snmpuad/article/view/3451.

[14] A. Prasasty, "Pengaruh disiplin dan motivasi belajar terhadap prestasi belajar matematika siswa kelas X SMK Bina Karya Insan Tangerang Selatan," J. Ilm. Pendidik. dan Ekon., vol. 1, no. 1, pp. 65-74, Feb. 2017, doi: 10.30599/UTILITY.V1I1.64.

[15] D. I. Kabupaten, K. Margunani, and A. Nila, "Pengaruh praktik kerja industri dan penguasaan mata diklat terhadap kesiapan kerja siswa SMK di Kabupaten Kendal [The Influence of Industrial Work Practices and Mastery of Training Eyes on Work Readiness of Vocational School Students in Kendal Regency]," Din. Pendidik., vol. 7, no. 1, pp. 1-7, 2012, doi: 10.15294/dp.v7i1.4911.

[16] S. Alifah, D. Narsih, and S. Widiyarto, "Pengaruh metode partisipatori dan minat belajar terhadap kemampuan berwirausaha siswa SMK [The Effect of Participatory Methods and Learning Interest on the Entrepreneurial Ability of Junior High School Students]," Lect. J. Pendidik., vol. 10, no. 1, pp. 66-81, Apr. 2019, doi: 10.31849/lectura.v10i1.2410.

[17] A. Ismayani and J. Pangeran Hidayatullah No, "Pengaruh penerapan stem projectbased learning terhadap kreativitas matematis siswa SMK [The effect of the application of STEM project-based learning on the mathematical creativity of vocational school students]," Indones. Digit. J. Math. Educ., vol. 3, no. 4, pp. 264-272, 2016, Accessed: Apr. 18, 2021. [Online]. Available:

http://idealmathedu.p4tkmatematika.org.

[18] W. Hanim, M. Mamesah, and R. R. Anzelyna, "Pengaruh Bimbingan Klasikal dengan Model Project Based Learning untuk Meningkatkan Tanggung Jawab Siswa [The Effect of Classical Guidance with the Project Based Learning Model to Increase Student Responsibility]," Insight J. Bimbing. Konseling, vol. 7, no. 1, pp. 56-71, Jun. 2018, doi: 10.21009/insight.071.05.

[19] S. Wahyuni, "Pengaruh keteladanan guru dan kesadaran diri terhadap disiplin siswa kelas X jurusan teknik kendaraan ringan (TKRO) otomotif SMK Negeri 1 Kebonsari Tahun Ajaran 2019/2020," IAIN Ponorogo, 2020.

[20] M. Aripin, "Hubungan Kesadaran Diri (Self Awareness) dengan Perencanaan Karir pada Siswa SMK Al Azhaar 
Tulungagung [Relationship Between Self Awareness (Self Awareness) and Career Planning in Al Azhaar Tulungagung Vocational School Students]," IAIN Tulungagung, 2020.

[21] T. F. Krisnamurti, "Faktor yang mempengaruhi kesiapan kerja siswa SMK [Factors affecting vocational students' job readiness]," J. Pendidik. dan Ekon., vol. 6, no. 1, pp. 65-76, Feb. 2017, Accessed: Apr. 18, 2021. [Online]. Available:http://www.kemenperin.go.id/ download/4556.
[22] J. A. Baser, N. A. M. Jizat, F. A. N. Yunus, M. B. Rahim, A. R. A. Razzaq, and A. Hasan, "Competency of National Dual Training System Industry Advisors," J. Pendidik. Teknol. dan Kejuru., vol. 23, no. 4, pp. 328-338, Oct. 2017, doi: 10.21831/JPTK.V23I4.14276. 